\title{
Huldyrch Zwingli's contribution to the Reformation
}

\begin{tabular}{|c|c|}
\hline \multicolumn{2}{|c|}{$\begin{array}{l}\text { Authors: } \\
\text { Jerry Pillay }{ }^{1} \text { (D) } \\
\text { Catherine McMillan }{ }^{1}\end{array}$} \\
\hline \multicolumn{2}{|c|}{$\begin{array}{l}\text { Affiliations: } \\
{ }^{1} \text { Department of Church } \\
\text { History and Church Polity, } \\
\text { Faculty of Theology and } \\
\text { Religion, University of } \\
\text { Pretoria, Pretoria, } \\
\text { South Africa }\end{array}$} \\
\hline \multicolumn{2}{|c|}{$\begin{array}{l}\text { Project Research Registration: } \\
\text { Project Leader: J. Pillay } \\
\text { Project Number: } 04653484\end{array}$} \\
\hline \multicolumn{2}{|c|}{$\begin{array}{l}\text { Description: } \\
\text { This research is part of the } \\
\text { project, 'African Christianit } \\
\text { and Development', directe } \\
\text { by Prof. Dr Jerry Pillay, } \\
\text { Department of Church } \\
\text { History and Church Polity, } \\
\text { Faculty of Theology and } \\
\text { Religion, University of } \\
\text { Pretoria. }\end{array}$} \\
\hline \multicolumn{2}{|c|}{$\begin{array}{l}\text { Corresponding author: } \\
\text { Jerry Pillay, } \\
\text { jerry.pillay@up.ac.za }\end{array}$} \\
\hline \multicolumn{2}{|c|}{$\begin{array}{l}\text { Dates: } \\
\text { Received: } 01 \text { July } 2019 \\
\text { Accepted: } 27 \text { July } 2019 \\
\text { Published: } 11 \text { Nov. } 2019\end{array}$} \\
\hline \multicolumn{2}{|c|}{$\begin{array}{l}\text { How to cite this article: } \\
\text { Pillay, J. \& McMillan, C., } \\
\text { 2019, 'Huldyrch Zwingli's } \\
\text { contribution to the } \\
\text { Reformation', HTS Teologiese } \\
\text { Studies/Theological Studies } \\
\text { 75(4), a5635. https://doi.org/ } \\
\text { 10.4102/hts.v75i4.5635 }\end{array}$} \\
\hline \multicolumn{2}{|c|}{$\begin{array}{l}\text { Copyright: } \\
\text { (C) 2019. The Authors. } \\
\text { Licensee: AOSIS. This wo } \\
\text { is licensed under the } \\
\text { Creative Commons } \\
\text { Attribution License. }\end{array}$} \\
\hline \multicolumn{2}{|l|}{ Read online: } \\
\hline 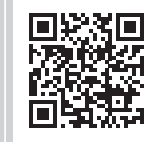 & $\begin{array}{l}\text { Scan this QR } \\
\text { code with your } \\
\text { smart phone or } \\
\text { mobile device } \\
\text { to read online. }\end{array}$ \\
\hline
\end{tabular}

Huldyrch Zwingli, the first Swiss reformer in Zurich, made significant contributions to the 16th-century Reformation, yet he remains relatively unknown, if not forgotten. He is generally overshadowed by other reformers, such as Martin Luther and John Calvin. This article attempts to bring Zwingli to the surface by examining some of his contributions in Zurich which impacted the Reformation at large. This is especially significant because 2019 marks the 500th anniversary of Zwingli. The aim of the article is to provide an overview of Zwingli's contributions to the Reformation and point out how his works, in given areas such as faith and society, theology and sacraments, have stimulated further developments and dialogues during the Reformation and beyond.

Keywords: Reformation; Zwingli; Luther; Swiss; Zurich; Reformed.

\section{Introduction}

The year 2019 marks the 500th anniversary of Huldyrch Zwingli who was one of the pioneering leaders in the 16th-century Reformation. Unfortunately, not much is known about him or celebrated as, for example, that of Martin Luther or John Calvin. The reformer's shade is found behind the Wasserkirche on the Limmat River, largely ignored except by a few tourists and the occasional pigeon (Gordon 2015:158).

What is known about Zwingli is often a negative impression. For example, he is repeatedly blamed for having inflicted upon the city a dreadful 'Puritanismus' that is anathema to modern creeds of diversity and acceptance. For contemporary citizens of Zurich, Zwingli has become the poster boy for all that is wrong with organised religion: narrow mindedness, intolerance and sexual repression (Du Magazine 1998). However, in the past few years much research has been conducted on the first reformer of the Swiss Reformation, and a new, fascinating and very positive picture of him has emerged.

Peter Opitz of the University of Zürich, an expert on Zwingli and the Swiss Reformations, says that "not Calvin but Zwingli is both historically and theologically the Father of the Reformed Protestant faith" (Opitz 'Ulrich Zwingli' 2015b:110). He adds further that because of Zwingli's groundbreaking ideas and good networking skills, the Swiss Reformation was not just a Swiss but a European Reformation, much more so than the Reformation of Martin Luther (Opitz 'Reformation' 2015a:69). McGrath (2012:83) points out that 'Calvin's success as a reformer owes more to Zwingli than is generally realised.' Oberman (2004:183) asserts that Zwingli was not accorded a comprehensive and balanced interpretation for centuries because he was constantly represented as somewhat inadequate when compared with Luther, or as dependent on the Wittenberg reformer.

Gottfried W. Locher (1981:42-70), a Zwingli specialist, in his research attempted to understand Zwingli on Zwingli's own terms, thus freeing him from the anathema pronounced on him by the Gnesio-Lutherans.

\section{Stephens (1986) adds that:}

$[A]$ study of Zwingli almost inevitably leads to comparisons between him and Luther, but always with the risk of distorting the presentation of Zwingli. Luther appears as the key to the reformation, the norm by which all other reformers and all other expressions of the reformation are judged. But Zwingli was not Luther, nor a variant of Luther. He was a reformer in his own right. (p. 1) 
The aim of this article is to show Zwingli as a valid and essential contributor to the 16th-century Reformation and, in some senses to, reclaim his position among the reformers. To achieve this, we will seek to explore Zwingli's contributions to the Reformation by (1) placing the Swiss Reformation in its historical context, (2) explaining how Zwingli's biography influenced the development of his thought and faith, (3) showing how the Swiss Reformation which began in Zürich contributed to the wider Reformation and (4) demonstrating how Zwingli's theological thinking contrasted with Luther's views, serving as a basis for Zwingli's contribution to the 16th-century Reformation in general.

\section{The historical context}

McGrath (2012:81) establishes that it is impossible to understand the career and strategy of the Swiss reformer Huldrych Zwingli without considering his background within the Swiss Confederation'. In the late Middle Ages, what is now Switzerland was a Confederacy of mostly selfgoverning territories, surrounded by affiliated regions. Many of the territories were rural, but some were city states with councils run by representatives of the guilds and the highest standing families of the town. In contrast, the feudal system still had a tight grip on Germany and most European countries. The Lords of a principality made the decisions for their people.

This is important in understanding how the Swiss Reformation caught fire and spread.

At the beginning of the 16th century, there was a power struggle going on between France and the Holy Roman Empire with its Habsburg emperor in Austria and the pope in Rome. These powers were fighting for important trade routes through the Alps and strategic territories. They made deals with the councilmen in Swiss regions for the right to recruit mercenaries or foot soldiers for their wars.

Bribes and trade alliances were offered. So young boys and men of the Swiss Confederacy were exported to foreign armies and ended up having to fight against each other. The church was heavily involved in the mercenary system and was making money from it. The wars were brutal. Whole villages were massacred.

The men came back traumatised. They drank and gambled. Domestic violence was prevalent. At the same time, the plague kept sweeping through, wiping out a fourth of the population each time. Life expectancy was low. Death was ever-present.

The church became susceptible to the influences of the Holy Roman Empire and wanted to cement its own power and keep the status quo (McGrath 2012:80-83). Bishops and priests were often corrupt. They found it easy to keep the people in check by cultivating their fears. They painted purgatory in the most graphic and grotesque way (McGrath 2012:2-10).
They claimed that buying a letter of indulgence would shorten your time in purgatory. Ulrich Zwingli was born into this context. Stephens (1986:3) establishes that the context of a person's writings does not account for them, but it helps to illuminate them. This, undoubtedly, is what we see in Zwingli's contributions to the Reformation.

\section{Ulrich Zwingli: The development of his thought}

Ulrich Zwingli was born on New Year's Day, 1484, in the Toggenburg valley in the canton of St Gallen, in the eastern part of modern-day Switzerland. It was not until he became an adult that he changed his name to Huldrych, which means 'rich in grace'. He was the son of a well-off farmer who was also the mayor of a mountainous area in East Switzerland. Zwingli grew up with a feel for public responsibility, with an eye for the real-life struggles and needs of the people. He was very intelligent, curious and musical. He played more than 10 instruments, and he composed.

Zwingli's early development was shaped by three factors that continued to influence his thought throughout his career: Swiss patriotism, Erasmian humanism and scholasticism (Stephens 1992:12). In one of his early writings as a reformer, he described himself as 'a Swiss professing Christ among the Swiss' (George 1988:110). Zwingli received a Renaissance-Humanist education in Basel and Vienna. The motto of humanism was ad fontes - back to the sources. Zwingli was influenced by Erasmus as a scholar whose humanist concerns led him to the New Testament and the fathers. For Zwingli, Erasmus had freed the Scriptures from scholasticism, and under his influence Zwingli became a theologian not in a scholastic but in a humanist sense (Stephens 1992:15).

Renaissance humanism was a method of learning based on an intellectual investment in ancient sources.

The goal of humanist pedagogy was not to see the writings from antiquity as a treasure chest preserving ancient truth, but as an access point to ideas, learning and argumentation that could direct both the thought and actions of people in their contemporary 16th-century world (Baschera, Gordon \& Moser 2014:12). It is quite clear that influenced by these humanist ideals, Zwingli took a great interest in interpreting and applying the Scriptures. This is notable in his work in Zurich as a preacher, theologian and reformer.

Plague besieged Zurich in 1519 just as Zwingli began serving in his new post as Leutpriester [parish priest]. In September 1519, he was infected by plague. While he had previously ministered to those dying of the illness in years past, nothing prepared him for the life-altering experience of his own dance with death (Eccher 2017:40). This is captured in a poem he penned in 1520 (Hendrix 2009): 
Help, Lord God, help in this trouble!

I think death is at the door.

Stand before me, Christ, for you have overcome him

To you I cry: If it is your will, take out the dart that wounds me,

Nor lets me have an hour's rest or repose.

Will you, however, that death take me in the midst of my days, so let it be.

Do what you will, nothing shall be too much for me.

Your vessel am I, to make or break altogether. (pp. 183-184)

There is no doubt that Zwingli's near-death experience was to shape his thoughts, development and theology. For example, this can be seen in his evolving sense of a merciful God which he greatly emphasised.

Born in a small Swiss village in the Toggenburg Mountains, Zwingli was exposed to the small village church which served as the centre of society and its cultural reach permeated all aspects of life. Therefore, Zwingli consumed a steady diet of Roman Catholic dogma alongside all the trappings of Rome's ceremony. This was all he knew and it would greatly shape his early years (Eccher 2017:34) as he kept in line with the teachings of the Roman Catholic Church. However, this was to change with time as he 'attacked Catholics, forcefully admonished the faithful and (supposedly) drowned Anabaptists' (see Gordon 2015:159). To gain further insight into this, we shall now look at his Reformation in Zurich.

\section{The Reformation of faith and society in Zürich}

At the end of 1518, Zwingli was accorded the honour of serving as 'people's priest' in Zurich. Once he began his work at Zurich on 01 January 1519, things were decidedly different; his priestly programme deviated from the standard clerical norm. It was this that unwittingly helped to propel Zurich towards the Reformation.

Perhaps, Zwingli's greatest contribution to the Reformation was the impact of faith in the transformation of society. His humanistic views became the link between church, society and theology.

According to Locher (1981:37), among the reformers, it was not Calvin, and certainly not Luther, but Zwingli, who strove for a theocracy; not, that is to say, the establishment of domination by the church or even by ministers, but rather that even public affairs should be directed by the Spirit of God. It was this strong belief which prompted Zwingli's active theocratic elements in the city and territory of Zurich. We shall now explore selected themes and events to illustrate Zwingli's connection of faith and society in the transformation of Zurich.

\section{The Gospel's social dimension}

Zwingli firmly believed that the Word has to renew the church and society; it has to be explicated and applied. Primarily for this reason, he preached his first sermon on
01 January 1519, his 35th birthday, disregarding texts prescribed by the church, and began with his lectio continua. That was the beginning of the Reformed practice of lectio continua - as opposed to the lectioselecta with its pericopes. He started interpreting the New Testament in Swiss German, beginning with Matthew, Chapter 1 and continued Sunday for Sunday. Similarly, he explicated the following books during the following 6 years: Acts, Timothy, the Epistles of Peter and Hebrews.

For Erasmus of Rotterdam, who taught in Basel, a humanist approach meant studying the Bible in its original languages. Influenced by Erasmus, Zwingli published a New Testament in Greek in 1515, based on his comparison of different original manuscripts. His New Testament was the basis for the Bible translations into the vernacular during the Reformation. For Zwingli, the Bible became the primary source of Christian faith and measure of sound Theology - no longer tradition, dogma, decisions of councils and popes. He was convinced that hearing the Gospel in its own language instead of Latin would change people's hearts and reform the church and society from the inside out. For him the Gospel was the life and work of Christ, and Christ calling and drawing us into joyful communion with God and with the community, showing us how to serve God. Not the doctrine of justification but Christ's call to reconciliation was central. The Gospel encompassed the individual, church and society.

Locher (1981:35-36) states that the Gospel became the central focus in Zwingli's work at which point all social, political and other questions were relegated to the background. Zwingli explicated the Scriptures to admonish and shepherd the Zurich faithful, express anti-mercenary attacks and address anti-clerical themes.

All of these ideas radically cast aside the traditions of Roman Catholicism and generated a sense of excitement and religious renewal, stirring the Reformation in Zurich.

\section{Calling out injustice and impacting society}

It was on the basis of Scripture Zwingli attacked a number of beliefs and practices of the medieval church, such as indulgences, tithes and the invocation of the saints - needless to say this provoked opposition to him (Stephens 1992:17). The Bible was also beginning to set him on a collision course of conflict with time-honoured ecclesiastical traditions: clerical celibacy, images, praying to the saints, the Mass and a customary tithe that permitted concubinage (Eccher 2017:38). Zwingli was driven by the Bible teaching on morality which stirred a conviction even in his own heart so much so that he married Anna Reinhard, whom he was living with secretly, to set aside his fornicating ways (Eccher 2017:38).

Zwingli's preaching of the Gospel embraced both his turning to Christ and his turning to Scripture. In his Clarity and Certainty of the Word of God in 1522, he spoke of the importance of learning God's teaching from God's plain word, and seeking understanding from God rather than from 
commentaries and expositors (Stephens 1992:21). It is thus not surprising that the Bible was at the heart of Zwingli's Reformation. That is why at the first disputation in January 1523 he could point to the Bible as the judge. At the heart of the Reformation was the rediscovery of the Bible; this was no different for Zwingli when compared with other reformers. The experience of true illumination grasped him and never let go of him. He heard of the voice of the loving Christ in the Scriptures.

For centuries, Zwingli's preaching has caused foreign mercenary service to be a pressing question of conscience, and particularly the 'pension system' linked to it that creates a financial interest in militarism (Locher 1981:16). In 1515 at the Battle of Marignano near Milan, Italy, he witnessed how the Swiss had to fight each other - some fighting for the French, most for the Pope. Many of the 14000 casualties were Swiss. Zwingli was shocked and enraged and started preaching against the mercenary system that he continued to do in Zurich. He said it was selling people for greed. The merchants, politicians, bishops and cardinals had blood on their fine, expensive clothes, he said. The immorality of the mercenary service, Zwingli reckoned, was a cancerous growth in the body of the church. War was nothing but mass murder.

Zwingli underlined his attack on the mercenary activities of the Confederates with the statement that 'God punishes evil men with evil' - wars are always a divine punishment. 'There is no nation or kingdom which has risen through war, which has not later fallen through war' (Locher 1981:115). It is rather ironic that Zwingli himself was killed by a sword. While he spoke against war he accepted the theory of the 'just war' and he used this to fearlessly defend the Gospel. The profound impact of the rediscovery of the Bible, coupled with his love for his country, did not allow him any peace. The Zwingli statue in Zurich captures this perplexed and confusing character with a Bible in one hand and a sword in the other. Zwingli's intentions were unmistakable; he sought to force the Catholic acceptance of the evangelical faith and to couple the Word of God with the military might of Zurich to achieve his martial purpose (Gordon 2015:159). His main concern was that the Swiss avoid foreign entanglements, not armed conflict altogether (Potter 1976:35-36).

Getting back to his attack on the mercenary system, Zwingli saw it as the root cause of poverty. Whole valleys were reduced to poverty because the women, children and old people could not cope with the work, while the men were wasting their energy in some war or other, and, as Zwingl put it, 'were killing people for money' (Locher1981:34). Zwingli was also concerned about the mental, emotional and physical injuries on the men when they returned from battle. He accused the church of placing additional burdens on people, rather than lifting their burdens. Zwingli called out legalism, corruption, greed and hypocrisy in the name of the Gospel of Christ.
As part of his care for the poor and needy, Zwingli set up a soup kitchen - called the Mushafen, the mush pot. Furthermore, convents were turned into hospitals and schools. Whoever did not have work, like monks out of a job, received job training. Begging was outlawed.

The commission that organised everything and kept the lists was made up of representatives of the city council and two advisory ministers of the church. The first reformed state welfare system in Zurich became a model for many similar institutions in Europe. This inevitably became the guiding factor of the Reformation because Zwingli believed that you could not engage religious reform without at the same time seeking political, economic and social reform and transformation as well. The 16th-century Reformation was to extend beyond the church and theology into transforming society, economics and politics as well; this is clearly seen in the contributions of Zwingli as shown above. This, inevitably, also had a bearing on the rights of women which we will now explore.

\section{Women's rights and public schools}

On the subject of women's rights, Zwingli and the city council established the first civil status office where weddings could be officially registered. Also, divorces were legalised under certain circumstances. This protected above all the rights of women. Arranged or forced marriages were made illegal. The legal marriage age for women was raised to 19 .

Zwingli was definitely not a feminist, but he was at least concerned about the welfare of women. Besides that, girls were taught to read like boys. He believed that everyone should be able to read the Bible and participate. For this reason, perhaps, public schools were one of the fruits of the Reformation that has affected modern life and improved many lives and afforded more equal opportunity. The Swiss Reformation was an education movement and a movement of social reform in as much as it was religious from the outset.

Zwingli tried to convince the Bishop in Constance, who was his boss, that nothing in the Bible says that priests cannot marry. To the contrary, they should be good husbands. It was to no avail. Priests were allowed to keep a woman and children, as long as they paid a yearly fine to the Bishop in Constance.

The Bishop was not interested in cutting off this steady source of income. But the women who were kept were considered prostitutes. Their children were illegitimate. They had no rights or social standing. Zwingli saw the hypocrisy and injustice of this practice. Thus, after 2 years of living secretly with Anna Reinhart, they got married publicly in the Great Minster. In his own way, Zwingli affirmed the rights of women. The debate on the ministry and ordination of women in the church, also in Protestant and Reformed churches, continues even today, but Zwingli, at least, opened the door for conversation on this subject in the Roman Catholic Church during his time. 


\section{The sausage scandal of 1522 and the first disputation of 1523}

Zwingli's rise to fame from being a relatively unknown cleric came through a debate over eating sausages during Lent in 1522. Several of his friends, including the printer Christoph Froschauer, broke the Lenten fast by consuming meat. Although Zwingli did not participate in this act, he quickly took to print and disputation to defend the freedom of a Christian and denounced the church's decree on fasting. He subsequently defended the act from the pulpit by preaching and publishing a sermon to defend the act of disobedience, biblically. It was a manifest of Christian freedom with the title: 'Regarding the Choice and Freedom of Food'.

After that, the Bishop wanted Zwingli handed over for trial. It was the time of inquisitions, beheadings and burnings at the stake for heretics.

The city council protected Zwingli. Then they organised a public debate - the Bishop's representatives against Zwingli. Whoever had the best biblical arguments would win. Six hundred people came to witness the disputation in the town hall of Zürich on 05 January 1523. Zwingli prepared and delivered 67 theses. The Council proclaimed Zwingli the winner.

The revolutionary thing about this is that a political authority gave a verdict on religious matters in the city.

The Council, representing the people, had taken things concerning the church into their own hands, based on the model of local councils in the Acts of the Apostles. The Council took on the role of bishop. This practice of public disputation was copied all over Europe as a means of introducing the Reformation in the Holy Roman Empire. So the Council ordered in 1523 that Zwingli continue preaching the Bible. This provided a path towards formally establishing the Reformation in Zurich. The Word of God would be the guiding light for the community and Zwingli would carry the lamp (Eccher 2017:42). Many reforms followed, all decided on by the Council. The relationship between state and church is an ongoing debate which we shall return to later. However, here we can see how Zwingli's working with the state supported his contributions to the Zurich Reformation. This can be seen further in his dealing with the Anabaptists.

\section{The radical left wing of the Reformation}

The first Anabaptists (the word means re-baptisers) as they were called were Zwingli's friends from the beginning. Anabaptism seems to have first arisen around Zurich, in the aftermath of Zwingli's reforms within the city in the early 1520s (McGrath 2012:9). But they soon came up with reforms based on their reading of the Sermon on the Mount that went further than Zwingli and the Council was willing to go. For example, Conrad Grebel (ca. 1498-1526) argued that Zwingli retained a number of practices - including infant baptism, the close link between church and magistracy, and the participation of Christians in warfare - which were not sanctioned or ordained by Scripture. Therefore, 'Anabaptism' is often referred to as the 'left wing of the Reformation' or the 'radical Reformation' (McGrath 2012:9).

Although Zwingli had sympathised with their position on baptism at the beginning, he found a way to legitimise the baptism of infants by interpreting the New Testament against the background of the Old Testament. Zwingli taught that the sacrament of baptism replaced the rite of circumcision in the Old Testament. It made a child part of the Covenant People.

That was the beginning of the Covenant Theology that has been so predominant in Reformed thinking. Zwingli not only further nuanced this premise to combat the radicals over time, but also established it as the foundation upon which Heinrich Bullinger and John Calvin would later build their Reformed Covenantal theology.

Added to his response to the Anabaptism, Zwingli deliberated on the idea of the visible and invisible church. He was against the Anabaptists' claiming to know who was a true Christian.

He said that the visible church is the congregation gathered to worship God. But we cannot see who all belongs to the invisible church, the Body of Christ worldwide. Only God knows.

So he was also against refusing admission to the Lord's Table on moral or theological grounds. Christ calls, therefore the invitation is open. Because the Lord's Supper is a celebration of reconciliation, it could also be a place where impenitent sinners may return and repent.

The Anabaptist views on the link between church and magistracy and the Christian participation in warfare put Zwingli in a very tough place. He was against war, too, but not against defending the city from enemies. Different to the Zurich Anabaptists, Zwingli always accepted the existing political order and the decisions of the legitimate political authorities.

He did not want anarchy to break out. At that time the complete separation of church and state was unthinkable. They were highly interdependent. Baptism and the regular oath made one a citizen.

In 1526, Zwingli worked closely with the city council to make rebaptism a crime punishable by death, based, in large part, on a historic link between rebaptism and the Donatist heresy. On 05 January 1527, Zwingli had the unfortunate experience to oversee the drowning of Felix Manz, his former student and friend who had betrayed his teacher by playing a key role in the re-baptisms of 1525 (Eccher 2017:44). Between 1527 and 1532, six Anabaptists were drowned in the Limmat River, not because of religious heresy but because of persistent disobedience to the political authorities. 
Official apologies were made by the City of Zürich and the Reformed Church of Zürich in 2004. Since then, the Mennonites and the Reformed are friends and work together, which is something Zwingli would be happy to know. Today there are far more tolerance on these matters than what was prevalent in the 16th century; however, the issues surrounding baptism are still with us.

\section{Mass, images and idolatry}

For Zwingli, the Bible was at the heart of worship. A service was basically hearing God's word and responding - with prayer and with a pious life all throughout the week. And doing one's job on a weekday was also a way of worshipping and glorifying God. It was being active and creative as images of God, the Creator. This idea developed into the work ethic and spirit of ingenuity that Protestants are famous for. The concept of sola scriptura became the dominant feature of the Reformation.

The Word of God thus played the central role in worship. The liturgical elements are not intended to provide a 'frame' for the sermon nor does it have the task of containing and balancing the subjectivity of preaching. The congregational service or response (prayers, lessons, creeds, etc.) is simply the congregation's way to the Word, and then the way back from the Word, and out into life with the Word (Locher 1981:18). With this understanding of worship and Word, Zwingli removed all statues, icons and images from the church. Although he was a talented musician himself, he banned music and images from the church. He was concerned that people were praying to statues and putting their trust in relics instead of in God. For Zwingli, the church design became a lecture hall with a high pulpit in the centre to demarcate the centrality of the Word and to resist idolatry.

The theme of idolatry remains important for the Reformed faith today. Many Reformed confessions of Faith, like the Theological Declaration of Barmen (1934) and the Belhar Confession (1982) in South Africa, call people of faith to stand up against idolatry in all forms - the idolatry of racism, of apartheid or of worshipping a Fascist leader. The Confession of Accra (2004) spoke out against unbridled capitalism and our responsibility for God's creation, in covenanting for justice and peace.

On another note, Zwingli considered church art, relics of saints and artefacts as a waste of money and a burden on the poor, who were heavily taxed to pay for these things. Moreover, they encourage superstition.

The money saved by doing away with sanctuary art and relics was used to help the poor. For Zwingli, the poor are the true images of God.

Zwingli did not stop at this; he went further to call the celebration of mass idolatry because people were worshiping a host, which actually only symbolised Christ. Christ's grace could not be distributed by humans, he said. Rather, it is freely given by the Holy Spirit.

For Zwingli, communion was about reconciliation with God and with others in the community of faith - through Christ. The bread was passed around so that one could be reconciled with one's brother or sister as the bread was shared. At the table sinners were gathered, invited directly by Christ himself, as in the parable of the beggars invited to the great banquet in Luke 14. Christians are gathered to be reconciled and strengthened for service in the world and for the mission of reconciliation. Thus, for Zwingli, the Mass became a simple meal of remembrance and fellowship (we will discuss this later). In ecumenical circles, it is no longer acknowledged that the Mass actually represents the norm of Christian worship. It would be true to say that Zwingli's contributions to this understanding were essential.

All of the above shows some ways in which Zwingli attempted to reform Zurich; it also serves as an indicator to outline his pioneering work that ultimately contributed to the Protestant Reformation. It is clear that Zürich was a city becoming more autonomous, more democratic, more selfgoverning, under the influence of new values, discovered in the Bible. Zwingli is not usually recognised for his steering work because he is often overshadowed by another reformer, Martin Luther. In the next section, we will continue to refer to Zwingli's contribution to the16th-Century Reformation by contrasting his theological views with that of Luther. The intention is not to get engrossed in theological debate, but to show Zwingli's unique contributions to Reformation theology.

\section{Zwingli's theological contributions}

Zwingli's sudden death in 1531 meant that he did not have sufficient time to fully develop his theology like Luther or Calvin; yet his contributions were enormous. Eccher (2017) makes this point:

Though, deceased, Zwingli's theology continued to give life, direction and inspiration to the Zurich Church for generations. Several of Zwingli's key theological beliefs are presently found in certain modern day Presbyterian and Baptist traditions, demonstrating his importance to the Protestant heritage. (p. 50)

Embedded in his context, Zwingli's theological views were influenced and shaped in the encounters in Zurich. It is in this sense that his theological views differed from that of Luther and other reformers. We shall now briefly show this as we look at the contrast of theological views between Zwingli and Luther.

Zwingli, like Luther, came to the Reformation faith through a deep and profound fear of God (Gordon 2015:163; Stephens 1986). However, unlike the German reformer, for the Swiss priest transformation emanated not from a personal crisis of spiritual torment but from an Old Testament sense that an idolatrous people stood before the immediate judgement of 
God (Gordon 2015:126). It is thus not surprising that Zwingli embraced and promoted an evangelical understanding of the Gospel, and this prompted his Reformation in Zurich addressing the current realities of his time. Perhaps it is against this backdrop that Oberman (1994) makes a somewhat exaggerated comparison of Luther and Zwingli:

These two great reformers were born hardly seven weeks apart - yet they are separated by the space of an entire epoch. In short, Luther was experiencing the End of Time; Zwingli lived in modern times. (p. 195)

He communicated a clear sense of a godly Christian community, arguing that the kingdom of God is visible in the here and now, that society could be transformed through the Word. For this reason, Zwingli has been often praised for his 'modernity' and is perceived by liberal theologians of the 19th century as a precursor of their own vision of a cultural Protestantism (Opitz 2008:957).

According to Locher, Zwingli's doctrine of God and his Pneumatology are deeply connected with his Christology. In comparison with Luther's 'Christology of Christmas', Zwingli's, however, can be characterised as a 'Christology of Easter and Ascension of Christ' (Locher 1979:207). Luther put Christ at the centre of his theologia crucis and drew a distinction between righteousness by faith and righteousness by works. Zwingli's theology, on the contrary, is a theology of reconciliation and liberation through God in Christ. Therefore, the centrality of Christ, like Luther, is beyond doubt. In fact, Zwingli put so much of emphasis on the divinity of Christ that Luther attacked him stating that the Swiss reformer had too radically separated Christ's human and divine natures, undoing the Chalcedonian formula.

For Zwingli, 'theocentricity' and 'christocentricity' are no alternatives (Stephens 2004:84). The Gospel liberates one to a life of faith. Faith, from a theological angle, is the free gift of God's spirit. As a consequence, faith is an essential liberation from all human bonds and all divinisation of the world which motivates us to do the will of God within the world, and to design it actively. Faith is the assurance in the merit of Christ and individuals are freed from any sense of having to merit faith and, as Luther had argued, justification is a wholly divine act. For Zwingli, however, the discussion of faith was always closely linked to human response, in which life is transformed to doing God's work in the world. Zwingli believed that the more faith develops, the more God is in you, and the more God is in you, the greater the work of good within you. It is this belief that compelled Zwingli's Reformation in Zurich.

It is this view that also informed Zwingli's understanding of the relationship between state and church. For Zwingli, church and state are not two separate communities, but one and the same community under the sovereign rule of God (Stephens 2004:123). This meant that the minister and the magistrate are concerned with the whole life of the community and not just part of it. In this, each is the servant of God, with different roles to play. His view in this regard distinguished him sharply from not only Luther but also from Calvin and other reformers.

Zwingli shared Luther's distinction between the spiritual and the political spheres. However, while Luther emphasised the difference of the two spheres (referred to as the two 'kingdoms'), Zwingli emphasised their interrelatedness. Zwingli was convinced of the duty of a Christian community to orient its laws towards God's will while accepting the necessary limitations and imperfection of human justice. He was, after all, a realist. If politics, economics and social relationships were not at least informed by the standards of divine justice, the strong would always dominate and the weak would be oppressed (Zwingli 1995b:175-176). The 39th of his 67 theses states: ' $[t]$ herefore all of their laws should be according to the divine will, so that they protect the oppressed, even if the oppressed do not claim their rights' (Zwingli 1995a:371).

In the modern age, Zwingli's directions concerning the state are no longer tenable (Locher 1981:38). Calvin was more farsighted; he began to separate the responsibilities of church and state. While there is a generally accepted view about the separation between church and state, yet this relationship is still a source of continued tension today.

\section{The sacraments}

The sharpest difference between Zwingli and Luther is to be found in their understanding of the sacraments.

His conflict with Luther over the Lord's Supper was not just mere semantics. The German and Swiss reformers held profoundly different interpretations of the nature of Jesus Christ, of how God is present in the world and of the relationship between the material and spiritual worlds.

Amidst his efforts to reform the Zurich Church in the early 1520s, Zwingli initially retained the Roman Catholic notion that God acted in the sacraments, even as he jettisoned the idea that this activity was salvific (Eccher 2017:36). However, by 1525 the Swiss preacher reversed his position entirely. He was averse both to the doctrine of transubstantiation and to seeing the sacraments functioning as a means of saving grace. He saw the Catholic and Lutheran teaching on the sacraments as an assault on God's freedom. His teaching on the Lord's Supper, usually designated 'memorialist' or 'real absence', taught that the bread and wine of the Lord's Supper are outward signs of faith that engage the senses and direct them to Christ. They are symbols through which the Spirit works, but in themselves they do not convey grace or impart faith. He denied agency to a material object. The same principle was at work in Zwingli's understanding of baptism. For Zwingli, baptism was a rite of initiation, a mark of entry into the church. Baptism as a ritual does not summon God, nor does it cause anything to happen. Like the Lord's Supper, baptism was an outward expression of what God has already done in Christ.

Eccher (2017:46) points out that Zwingli's reaction was not a mere reaction, but mostly a by-product of his humanistic 
hermeneutic. Drawing heavily from Erasmus, he believed that the literal meaning of the Bible was dictated by historical context. Because Jesus was physically present at the institution of Supper, any corporeal presence must be rejected, and because Jesus was presently seated at the right hand of the Father physical presence in the elements was precluded. Zwingli emphasised the 'natural' rendering of the text given the immediate context. Although Luther at first left it to others to respond when Zwingli's position on the Supper began to resonate with other prominent figures, Luther was eventually forced to enter the debate. This subsequently led to the Marburg Colloquy in 1529. Even as the reformers at Marburg agreed on 14 of the 15 doctrinal matters of Protestant theology discussed at the colloquy, they left divided and discouraged.

Zwingli's theological views were picked up and taken further by his successor, Heinrich Bullinger. And though Bullinger had the unenviable task of mediating his mentor's theology and legacy to an ever-changing early modern world, the young preacher was up to the task. Not only Bullinger, but John Calvin also embraced and took Zwingli's theological contributions further. Although deceased, Zwingli's theology continued to give life, direction and inspiration to the Zurich Church for generations. Several of Zwingli's key theological beliefs are presently found in certain modern-day Presbyterian and Baptist traditions, demonstrating his importance to the Protestant heritage.

\section{Conclusion}

In celebrating the 500th anniversary of Huldrych Zwingli in 2019 , this article has set out to explore the contributions of this reformer to the Reformation in Zurich and to the 16th-century Reformation in general. Zwingli is often not recognised or accorded his rightful place in his contributions to the Reformation because he is hugely overshadowed by reformers such as Luther and Calvin. The article has selected certain themes and events to explore, examine and unpack some of Zwingli's contributions to help set him apart as a giant reformer and theologian in his time rather than simply one who lives in the shadow of other reformers. Zwingli's Reformation in Zurich and his theological views continue to impact Christians and the world at large even today. We believe that this article would increase the appreciation and recognition of this great reformer in his own right and context.

\section{Acknowledgements}

The author would like to thank the Rev Catherine McMillan for her assistance in conducting this research.

\section{Competing interests}

The authors have declared that no competing interests exist.

\section{Author(s) contributions}

All authors contributed equally to this work.

\section{Ethical considerations}

This article followed all ethical standards for a research without direct contact with human or animal subjects.

\section{Funding information}

This research received no specific grant from any funding agency in the public, commercial or not-for-profit sectors.

\section{Data availability statement}

Data sharing is not applicable to this article as no new data were created or analysed in this study.

\section{Disclaimer}

The views and opinions expressed in this article are those of the authors and do not necessarily reflect the official policy or position of any affiliated agency of the authors.

\section{References}

Baschera, L., Gordon, B. \& Moser, C., 2014, Following Zwingli: Applying the past in reformation Zurich, Ashgate, Surrey.

Du Magazine, 1998, Zwingli's Zurich, Das Perfekte Alibi.

Eccher, S.B., 2017, 'Hulydrych Zwingli: Reformation in conflict', Perichoresis 15(4), 33-53. https://doi.org/10.1515/perc-2017-0021

George, T., 1998, Theology of the reformers, Boardman Press, Youngstown, OH.

Gordon, B., 2015, 'Hulydrych Zwingli', The Expository Time 126(4), 157-168. https:// doi.org/10.1177/0014524614560493

Hendrix, S.H., 2009, Early protestant spirituality, Paulist Press, New York.

Locher, G.W., 1981, Zwingli's thought: New perspectives, E. J. Brill, Leiden.

Locher, G.W., 1979, Die Zwinglische Reformation in Rahmen der europaischen kirchengeschichte, Vandenhoeck und Rupert, Gottingen.

McGrath, A.E., 2012, Reformation thought: An introduction, Wiley-Blackwell, Oxford.

Oberman, H.A., 2004, The reformation roots and ramifications, T \& T Clark International, London.

Opitz, P., 2015a, 'The Swiss contribution to the reformation movement', in P. Bosse-Huber (ed.), Reformation: Legacy and future, pp. 67-76, Geneva World Council of Churches Publications, Geneva, viewed from https://www.academia. edu/15358770/The_Swiss_Contribution_to_the_Reformation_Movement.

Opitz, P., 2015b, Ulrich Zwingli: Prophet, Ketzer, Pionier des Protestantismus, TVZ Theologischer Verlag Zürich, Zürich.

Opitz, P., 2008, 'Ulrich Zwingli', Religion Compass 2(6), 949-960. https://doi.org/ 10.1111/j.1749-8171.2008.00106.x

Potter, G.R., 1976, Zwingli, Cambridge University Press, Cambridge.

Stephens, W.P., 1986, The theology of Huldrych Zwingli, Clarendon Press, Oxford.

Stephens, W.P., 1992, Zwingli an introduction to his thought, Clarendon Press, Oxford.

Stephens, W.P., 2004, 'The theology of Zwingli', in D. Bagchi and D.C. Steinmetz (eds.), The Cambridge companion to Reformation Theology, pp. 80-99, Cambridge University Press, Edinburgh.

Zwingli, H., 1995a, 'Auslegung und Begründung der ThesenoderArtikel, 1523', Schriften II, TVZ TheologischerVerlag Zürich, Zürich.

Zwingli, H., 1995b, 'Göttliche und menschlicheGerechtigkeit, 1523', Schriften I, pp. 175-176, TVZ TheologischerVerlag Zürich, Zürich. 